\section{(2) OPEN ACCESS}

\title{
'Kinesinopathies': emerging role of the kinesin family member genes in birth defects
}

\author{
Silvia Kalantari 이, ${ }^{1}$ Isabel Filges (1) 1,2
}

- Additional material is published online only. To view, please visit the journal online (http://dx.doi.org/10.1136/ jmedgenet-2019-106769).

${ }^{1}$ Medical Genetics, Institute of Medical Genetics and Pathology, University Hospital Basel and University of Basel, Basel, Switzerland

${ }^{2}$ Department of Clinical Research, University Hospital Basel and University of Basel, Basel, Switzerland

\section{Correspondence to}

Dr Isabel Filges, Medical Genetics, University Hospital Basel, Basel 4031, Switzerland; isabel.filges@unibas.ch

Received 10 December 2019 Revised 23 March 2020 Accepted 28 March 2020 Published Online First 19 May 2020
Check for updates

(C) Author(s) (or their employer(s)) 2020. Re-use permitted under CC BY-NC. No commercial re-use. See rights and permissions. Published by BMJ.

To cite: Kalantari S, Filges I. $J$ Med Genet

2020:57:797-807.

\begin{abstract}
Motor kinesins are a family of evolutionary conserved proteins involved in intracellular trafficking of various cargoes, first described in the context of axonal transport. They were discovered to have a key importance in cellcycle dynamics and progression, including chromosomal condensation and alignment, spindle formation and cytokinesis, as well as ciliogenesis and cilia function. Recent evidence suggests that impairment of kinesins is associated with a variety of human diseases consistent with their functions and evolutionary conservation. Through the advent of gene identification using genomewide sequencing approaches, their role in monogenic disorders now emerges, particularly for birth defects, in isolated as well as multiple congenital anomalies. We can observe recurrent phenotypical themes such as microcephaly, certain brain anomalies, and anomalies of the kidney and urinary tract, as well as syndromic phenotypes reminiscent of ciliopathies. Together with the molecular and functional data, we suggest understanding these 'kinesinopathies' as a recognisable entity with potential value for research approaches and clinical care.
\end{abstract}

\section{INTRODUCTION}

The mammalian kinesin superfamily proteins (KIFs) are microtubule and ATP-dependent molecular motors, which were first identified in 1985 as axonal transporters in squid and bovine brains. ${ }^{1}$ Forty-five different kinesin family member (KIF) genes were identified in the mouse genome so far, 44 of which are present in the human genome. Phylogenetic analysis based on sequence homology between the human and the mouse genome led to the classification of KIF genes into 16 families, from kinesin-1 to kinesin-14B (figure 1). ${ }^{2}$ The first kinesins discovered belong to the kinesin-1 family (KIF5A, KIF5B and KIF5C), and they form a heterotetramer of two heavy chains and two light chains (KLC1-4). ${ }^{2}$ KIF genes encode KIFs, a specific class of motor proteins generating intracellular motility by driving directional transport of various cargoes such as organelles, protein complexes and mRNAs along the microtubule system. ${ }^{2}$ Studies using knockout mouse models by Hirokawa and colleagues significantly contributed to elucidate the roles of kinesins in mammalian physiology. Their role in transport is fundamental to cellular logistics and performance, and the molecular motors are not only effectors of signal transduction cascades but also transport and/ or bind to important signal transduction molecules to actively modulate their function. ${ }^{3}$
The first kinesins were observed in the context of axonal transport in neurons, and a novel disease entity of 'motor-proteinopathy' was proposed for the pathogenesis of axonal neuropathies in $2001 .{ }^{4}$ Due to their role in cellular membrane trafficking, however, kinesins are essential for the functioning of many polar cell types, such as neurons, epithelial cells, sperm cells or stem cells during organogenesis. Kinesins also play a fundamental role in cellcycle dynamics, both during mitotic and meiotic processes. They regulate chromosomal condensation and alignment, spindle formation, cytokinesis and cell-cycle progression. ${ }^{5}$ It is estimated that about a dozen kinesins are involved in the cell cycle. Among these, there is a specific subclass of chromokinesins (kinesin 4 and kinesin 10 family) which are able to bind chromosomes. ${ }^{6}$ Recently, KIFs were discovered to act as microtubule stabilisers (KIF26A and KIF21A) and depolymerisers (KIF2A and KIF2C), activities which are important for both cellular morphogenesis and mammalian development, playing a role in neuronal and axonal morphology and ciliogenesis. ${ }^{7}$

Alterations in motor kinesins are leading to human disease by various pathological mechanisms, including cancer and multifactorial and monogenic disorders. Variants in 18 out of the 44 human KIF genes were identified to cause monogenic disorders, following different modes of Mendelian inheritance and associated with a wide spectrum of clinical signs. These range from lethal and multiple to isolated congenital anomalies-including birth defects potentially detectable in the foetal period by current prenatal imaging studies - to postnatally apparent neurodevelopmental disorders, intellectual disability and neurological conditions.

We will review the current state of knowledge of the biological processes kinesins are involved in and discuss their emerging role in human disease, particularly in birth defects and congenital anomaly syndromes. Birth defects remain a leading cause of perinatal lethality in industrialised countries. ${ }^{8}$ Structural anomalies are recognised with increasing reliability during early pregnancy by the use of highresolution ultrasound technologies, thus raising questions about diagnosis, aetiology, prognosis and recurrence risk, particularly in the presence of more than one anomaly, which most likely indicates a genetic aetiology. We identify recurrent phenotype patterns caused by alterations in KIF genes, and we outline the complexity of phenotype-genotype correlations mirroring the processes of intracellular microtubule-mediated transport and movement, in which kinesins play a fundamental role. There are 


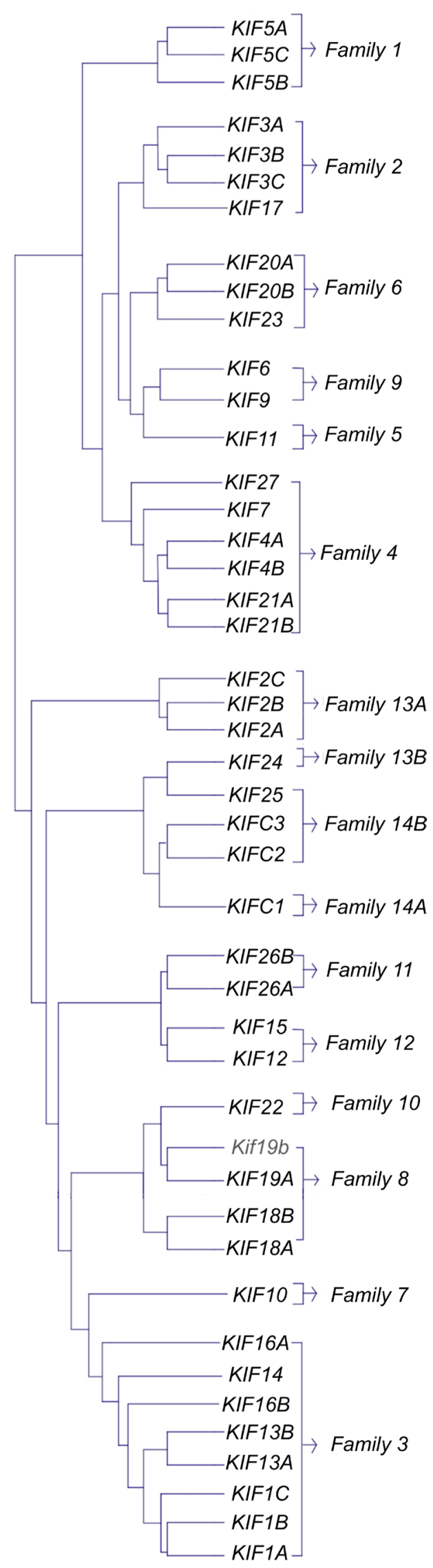

Figure 1 Phylogenetic tree of mammalian kinesin superfamily genes identified in the human (and mouse) genome and classified in 16 subfamilies (from kinesin 1 to 14B) (adapted from Hirokawa et a $\beta^{3}$ ). likely many more relationships between the clinical signs and the genetic variants to be identified in the future, and the functional network of kinesins and their role in human disease need to be further elucidated. We propose to introduce the term 'kinesinopathies' for this group of conditions, which are phenotypically and genetically overlapping and characterised by the functional impairment of a specific group of molecular motors. We hope that their systematic approach leads to a better recognition in clinical practice, as well as in genome-wide sequencing for diagnosis and research, and opens strategies for the future development of molecular therapies.

\section{KIF STRUCTURE}

All KIFs have a phylogenetically well-conserved motor domain head, consisting of an ATP-binding motif and a microtubulebinding domain. Depending on the position of the motor domain, kinesins can be subdivided into $\mathrm{N}$-kinesins (amino-terminal motor domain), M-kinesins (middle-region motor domain) and C-kinesins (carboxy-terminal motor domain). ${ }^{2}$ Most kinesins belong to the $\mathrm{N}$-kinesin subgroup, but members of the kinesin 13A family (figure 1 ) belong to the M-kinesin subtype, while KIF1C, KIF2C and KIF3C belong to the C- kinesin subfamily. ${ }^{3}$ Both $\mathrm{N}$-kinesins and C-kinesins are responsible for plus end and minus end-directed motility, M-kinesins for depolymerisation of microtubules in tubulin molecules. However, there are a few exceptions to this categorisation. ${ }^{9}$ The motor domain head attaches to the neck, the coiled coil stalk and the tail. The kinesins' neck is family-specific and responsible for the direction of motility or regulation of activity. The coiled coil stalk and tail are involved in kinesin dimerisation and/or interactions with cargoes. Kinesins typically use scaffold proteins and adaptor proteins to bind their cargoes but can sometimes bind the cargo directly. Scaffolds and adaptors might also have regulatory roles in kinesin-driven intracellular transport, that is, recognising specific cargoes and regulating their loading and unloading. ${ }^{3}$

\section{ROLE OF KIFS IN PHYSIOLOGY AND DISEASE}

The application of genome-wide sequencing for gene identification in research or for clinical diagnostic purposes significantly contributes to the identification of KIF candidate genes. Genotype-phenotype correlations in KIF gene-related disorders, together with functional and animal studies, continue to elucidate the complex involvement of KIFs in human developmental pathways and disease. Table 1 summarises the monogenic conditions caused by variants affecting the function of KIF genes.

The kinesins' functions in physiological processes, however, are complex and still incompletely understood, but their role in cell-cycle progression and regulation, including both meiosis and mitosis, in intracellular trafficking, axonal transport, microtubule activity and ciliogenesis, is increasingly studied. Figure 2 summarises the clustering of KIF genes according to their functional roles and the phenotypical consequences as identified to date in 32 out of the 44 human kinesin genes.

Kinesins play a pivotal role during early development and organogenesis. Microcephaly is one of the most frequently associated clinical signs, mirroring a defect in the regulation of the final number of neurons during development. ${ }^{10}$

KIF4A is a motor protein that translocates PRC1, a cytokinesis protein, to the ends of the spindle microtubules during mitosis, regulates the PARP1 activity in brain development and the survival of neurons, and is a member of the L1CAM recycling pathway. Variants in L1CAM cause X-linked isolated and 
Table 1 Specific monogenic disorders caused by variants affecting the function of KIF genes

\begin{tabular}{|c|c|c|c|c|c|c|}
\hline $\begin{array}{l}\text { Kinesin } \\
\text { family }\end{array}$ & KIF gene & Associated phenotypes, OMIM & Clinical description & $\begin{array}{l}\text { Cytogenetic } \\
\text { location }\end{array}$ & Inheritance & Variant type \\
\hline \multirow[t]{4}{*}{ Kinesin 1} & \multirow[t]{2}{*}{ KIF5A } & Spastic paraplegia type 10, \#604 187 & $\begin{array}{l}\text { Gait abnormalities, lower limb hyper-reflexia, spasticity } \\
\text { and weakness; upper limb spasticity and bladder } \\
\text { dysfunction frequent; sensory disturbances common; } \\
\text { variable phenotype, also including intellectual disability }\end{array}$ & $12 q 13.3$ & $A D$ & $\begin{array}{l}\text { Missense variants } \\
\text { Motor domain }\end{array}$ \\
\hline & & $\begin{array}{l}\text { Neonatal intractable myoclonus, } \\
\# 617235\end{array}$ & $\begin{array}{l}\text { Nystagmus, optic nerve pallor, myoclonus seizures, clonic } \\
\text { seizures, developmental arrest, delayed myelination, } \\
\text { athetoid and choreiform movements }\end{array}$ & $12 q 13.3$ & $A D$ & $\begin{array}{l}\text { Stop-loss frameshift variants } \\
\text { Cargo-binding domain }\end{array}$ \\
\hline & KIF5C & $\begin{array}{l}\text { Cortical dysplasia, complex, with } \\
\text { other brain malformations 2, } \\
\# 615282\end{array}$ & $\begin{array}{l}\text { Delayed psychomotor development, foetal akinesia, } \\
\text { spastic tetraplegia, seizures, malformations of cortical } \\
\text { development and arthrogryposis }\end{array}$ & $2 \mathrm{q} 23.1-\mathrm{q} 23.2$ & $A D$ & $\begin{array}{l}\text { Missense variants } \\
\text { Microtubule-binding domain }\end{array}$ \\
\hline & $K L C 2$ & $\begin{array}{l}\text { Spastic paraplegia, optic atrophy, } \\
\text { and neuropathy, } \\
\text { \#609541 }\end{array}$ & $\begin{array}{l}\text { Congenital optic atrophy, early-onset progressive spastic } \\
\text { paraplegia, hyper-reflexia, dysarthria, distal axonal motor } \\
\text { and sensory peripheral neuropathy }\end{array}$ & $11 \mathrm{q} 13.2$ & AR & $\begin{array}{l}\text { Missense variants } \\
\text { Motor domain }\end{array}$ \\
\hline Kinesin 2 & KIF3C & Sporadic infantile spasm syndrome ${ }^{58}$ & $\begin{array}{l}\text { Clinical spasms with ictal electrodecrement, usually } \\
\text { occurring before the age of } 1 \text { year and frequently } \\
\text { associated with cognitive impairment }\end{array}$ & $2 p 23.3$ & Candidate gene/AD & $\begin{array}{l}\text { Missense variant } \\
\text { Coiled-coil region }\end{array}$ \\
\hline \multirow[t]{9}{*}{ Kinesin 3} & \multirow[t]{3}{*}{ KIF1A } & $\begin{array}{l}\text { Hereditary sensory neuropathy type } \\
\text { IIC, \#614 } 213\end{array}$ & $\begin{array}{l}\text { Progressive sensory neuropathy, areflexia, hyporeflexia } \\
\text { and developmental delay }\end{array}$ & $2 q 37.3$ & AR & Truncating variants \\
\hline & & $\begin{array}{l}\text { Mental retardation, autosomal } \\
\text { dominant 9, \#614 } 255\end{array}$ & $\begin{array}{l}\text { Developmental delay, intellectual disability, microcephaly, } \\
\text { cerebellar atrophy, spasticity, possible seizures, hypotonia } \\
\text { and clubfoot }\end{array}$ & $2 q 37.3$ & $A D$ & $\begin{array}{l}\text { Missense variants } \\
\text { Motor domain }\end{array}$ \\
\hline & & Spastic paraplegia type 30, \#610 357 & $\begin{array}{l}\text { Lower limb spasticity, spastic gait, hyper-reflexia, lower } \\
\text { limb muscle atrophy and weakness }\end{array}$ & $2 q 37.3$ & AR & $\begin{array}{l}\text { Missense variants } \\
\text { Motor domain }\end{array}$ \\
\hline & KIF1B & $\begin{array}{l}\text { Charcot-Marie-Tooth disease, axonal, } \\
\text { type 2a1, \#118 } 210\end{array}$ & $\begin{array}{l}\text { Distal limb weakness and atrophy due to peripheral } \\
\text { neuropathy, foot drop, hyporeflexia, areflexia, pes cavus } \\
\text { and hammer toes; childhood onset of the disease }\end{array}$ & $1 p 36.22$ & $A D$ & $\begin{array}{l}\text { Loss-of-function variants } \\
\text { Motor domain }\end{array}$ \\
\hline & $\begin{array}{l}\text { KIF1BP / } \\
\text { KIAA1279 }\end{array}$ & $\begin{array}{l}\text { Goldberg-Shprintzen megacolon } \\
\text { syndrome, \#609 } 460\end{array}$ & $\begin{array}{l}\text { Intellectual disability, microcephaly and dysmorphic facial } \\
\text { features; Hirschsprung disease and/or gyral abnormalities } \\
\text { of the brain in most patients; megalocornea or urogenital } \\
\text { anomalies may also be present }\end{array}$ & $10 q 22.1$ & AR & Nonsense variants \\
\hline & KIF1C & Spastic ataxia type 2, \#611 302 & $\begin{array}{l}\text { Dysarthria, cerebellar gait ataxia, dysmetria, tremor, } \\
\text { spasticity of the lower limbs, hyper-reflexia and distal } \\
\text { muscle atrophy; onset in teenage years }\end{array}$ & $17 \mathrm{p} 13.2$ & AR & $\begin{array}{l}\text { Nonsense/truncating } \\
\text { variants/whole-gene } \\
\text { deletion }\end{array}$ \\
\hline & \multirow[t]{2}{*}{ KIF14 } & Meckel syndrome 12, \#616 258 & $\begin{array}{l}\text { IUGR, corpus callosum agenesis, cerebral and cerebellar } \\
\text { hypoplasia, flexion arthrogryposis, renal agenesis and } \\
\text { microcephaly }\end{array}$ & $1 \mathrm{q} 32.1$ & AR & Truncating variants \\
\hline & & $\begin{array}{l}\text { Primary microcephaly type 20, } \\
\# 617914\end{array}$ & Microcephaly, ID, autistic features; highly variable severity & $1 \mathrm{q} 32.1$ & AR & See table 2 for details. \\
\hline & KIF16B & $\begin{array}{l}\text { Novel autosomal recessive ID } \\
\text { syndrome }^{49}\end{array}$ & $\begin{array}{l}\text { Facial dysmorphism, microcephaly, hypospadias and } \\
\text { chordae, intellectual disability, seizures, brain atrophy and } \\
\text { thinning of the corpus callosum }\end{array}$ & 20p12.1 & AR & $\begin{array}{l}\text { Missense variants } \\
\text { PX domain }\end{array}$ \\
\hline \multirow[t]{8}{*}{ Kinesin 4} & \multirow[t]{4}{*}{ KIF7 } & Acrocallosal syndrome, \#200990 & $\begin{array}{l}\text { Severe intellectual disability, postaxial polydactyly, hallux } \\
\text { duplication, macrocephaly and absence of the corpus } \\
\text { callosum }\end{array}$ & $15 q 26.1$ & AR & $\begin{array}{l}\text { Frameshift/nonsense } \\
\text { variants } \\
\text { Throughout the gene }\end{array}$ \\
\hline & & Joubert syndrome 12, \#200990 & $\begin{array}{l}\text { ID, molar tooth sign on brain MRI, ataxia, agenesis of } \\
\text { the corpus callosum, hypertelorism, triangular mouth, } \\
\text { downslanting palpebral fissures, low-set ears, prominent } \\
\text { forehead and polydactyly }\end{array}$ & $15 q 26.1$ & AR & $\begin{array}{l}\text { Truncating variants/non- } \\
\text { sense mediated decay }\end{array}$ \\
\hline & & $\begin{array}{l}\text { Al-Gazali-Bakalinova syndrome, } \\
\# 607131\end{array}$ & $\begin{array}{l}\text { Macrocephaly, frontal bossing, hypertelorism, flattening } \\
\text { of the malar region, low-set ears, pectus excavatum and } \\
\text { carinatum, spindle-shaped fingers with interdigital soft- } \\
\text { tissue webbing, clinodactyly, genu valgum, swelling of } \\
\text { the joints, dysplasia of the epiphyses of the long bones, } \\
\text { agenesis of the corpus callosum and frontotemporal brain } \\
\text { atrophy }\end{array}$ & $15 q 26.1$ & $A R$ & $\begin{array}{l}\text { Missense variants } \\
\text { Structural maintenance of } \\
\text { chromosomes domain }\end{array}$ \\
\hline & & Hydrolethalus syndrome 2, \#614 120 & $\begin{array}{l}\text { Lethal developmental disorder: hydrocephaly, } \\
\text { arhinencephaly, upper limb postaxial polydactyly, hallux } \\
\text { duplication and molar tooth sign on MRI }\end{array}$ & $15 q 26.1$ & AR & $\begin{array}{l}\text { Microdeletion } \\
\text { Coiled-coil region }\end{array}$ \\
\hline & \multirow[t]{2}{*}{ KIF4A } & $\begin{array}{l}\text { Mental retardation, X-linked 100, } \\
\# 300922\end{array}$ & $\begin{array}{l}\text { Intellectual disability, seizures and mild facial } \\
\text { dysmorphisms }\end{array}$ & $\mathrm{Xq13.1}$ & $\mathrm{XLR}$ & $\begin{array}{l}\text { In-frame deletion, splicing } \\
\text { affected }\end{array}$ \\
\hline & & Isolated hydrocephalus ${ }^{11}$ & Hydrocehalus internus at 22 weeks of gestation & $\mathrm{Xq13.1}$ & $\begin{array}{l}\text { Candidate gene/ } \\
\text { XLR }\end{array}$ & $\begin{array}{l}\text { Missense variant } \\
\text { Coiled-coil domain }\end{array}$ \\
\hline & \multirow[t]{2}{*}{ KIF21A } & $\begin{array}{l}\text { Fibrosis of extraocular muscles, } \\
\text { congenital 1,\#135700 }\end{array}$ & $\begin{array}{l}\text { Ptosis, hypotropic strabismus, fibrosis of extraocular } \\
\text { muscles and compensatory backward tilt to the head }\end{array}$ & $12 q 12$ & $A D$ & $\begin{array}{l}\text { Missense variants } \\
\text { Stalk domain }\end{array}$ \\
\hline & & $\begin{array}{l}\text { Fibrosis of extraocular } \\
\text { muscles, congenital, 3B, \#135 } 700\end{array}$ & $\begin{array}{l}\text { Eyes in neutral primary position, residual upgaze and } \\
\text { absence of ptosis }\end{array}$ & $12 q 12$ & $A D$ & $\begin{array}{l}\text { Missense variants } \\
\text { Stalk domain }\end{array}$ \\
\hline Kinesin 5 & KIF11 & $\begin{array}{l}\text { Microcephaly with or without } \\
\text { chorioretinopathy, lymphoedema or } \\
\text { mental retardation, \#152950. }\end{array}$ & $\begin{array}{l}\text { Microcephaly, developmental delay, characteristic facial } \\
\text { phenotype, chorioretinopathy, retinal folds and congenital } \\
\text { lymphoedema }\end{array}$ & $10 q 23.33$ & $A D$ & Truncating variants \\
\hline Kinesin 7 & $\begin{array}{l}\text { KIF10/ } \\
\text { CENPE }\end{array}$ & $\begin{array}{l}\text { Microcephaly 13, primary autosomal } \\
\text { recessive, \#616 } 051\end{array}$ & $\begin{array}{l}\text { Microcephaly, poor overall growth, developmental delay, } \\
\text { dysmorphic facial features, severely simplified gyral } \\
\text { pattern with partial agenesis of the corpus callosum and } \\
\text { cerebellar hypoplasia }\end{array}$ & $4 q 24$ & AR & $\begin{array}{l}\text { Missense variants } \\
\text { Coiled-coil region }\end{array}$ \\
\hline
\end{tabular}




\begin{tabular}{|c|c|c|c|c|c|c|}
\hline $\begin{array}{l}\text { Kinesin } \\
\text { family }\end{array}$ & KIF gene & Associated phenotypes, OMIM & Clinical description & $\begin{array}{l}\text { Cytogenetic } \\
\text { location }\end{array}$ & Inheritance & Variant type \\
\hline Kinesin 10 & KIF22 & $\begin{array}{l}\text { Spondyloepimetaphyseal dysplasia } \\
\text { with joint laxity, type 2, \#603 } 546\end{array}$ & $\begin{array}{l}\text { Short stature, distinctive midface retrusion, progressive } \\
\text { knee malalignment (genu valgum and/or varum), } \\
\text { generalised ligamentous laxity and mild spinal deformity }\end{array}$ & $16 p 11.2$ & $A D$ & $\begin{array}{l}\text { Missense variants } \\
\text { Kinesin motor domain }\end{array}$ \\
\hline \multirow[t]{2}{*}{ Kinesin 11} & \multirow[t]{2}{*}{ KIF26B } & $\begin{array}{l}\text { Autosomal dominant spinocerebellar } \\
\text { ataxia }^{59}\end{array}$ & Spasticity and gait/limb ataxia and very slow progression. & $1 q 44$ & $A D$ & $\begin{array}{l}\text { Missense variants } \\
\text { Tail region }\end{array}$ \\
\hline & & $\begin{array}{l}\text { Pontocerebellar hypoplasia with } \\
\text { arthrogryposis }^{50}\end{array}$ & $\begin{array}{l}\text { Progressive microcephaly, right germinolytic cyst, } \\
\text { thinned corpus callosum, dysmorphic facial features, } \\
\text { camptodactyly, congenital dislocations of both } \\
\text { hips, congenital vertical talus (rocker-bottom feet), } \\
\text { arthrogryposis of upper extremities and myoclonic seizures }\end{array}$ & $1 q 44$ & Candidate gene/AD & $\begin{array}{l}\text { Missense variant } \\
\text { Kinesin motor domain }\end{array}$ \\
\hline \multirow[t]{3}{*}{ Kinesin 12} & \multirow[t]{2}{*}{ KIF12 } & Renal hypodysplasia ${ }^{52}$ & $\begin{array}{l}\text { Congenital megabladder, renal hyopdysplasia and } \\
\text { congenital vesicoureteral reflux }\end{array}$ & $9 q 32$ & Candidate gene/AD & CNV (duplication) \\
\hline & & $\begin{array}{l}\text { High gamma-glutamyltransferase } \\
\text { choleastasis }^{60}\end{array}$ & $\begin{array}{l}\text { Neonatal choleastasis, paucity of bile ducts, mild renal } \\
\text { pelvic abnormalities with unremarkable kidney function }\end{array}$ & $9 q 32$ & $A R$ & $\begin{array}{l}\text { Truncating/missense variants } \\
\text { Kinesin motor domain }\end{array}$ \\
\hline & KIF15 & Braddock-Carey-like syndrome ${ }^{54}$ & $\begin{array}{l}\text { Microcephaly, congenital thrombocytopenia, Pierre-Robin } \\
\text { sequence and agenesis of the corpus callosum }\end{array}$ & $3 p 21.31$ & $A R$ & $\begin{array}{l}\text { Nonsense variants } \\
\text { Coiled-coil domain }\end{array}$ \\
\hline Kinesin 13 & KIF2A & $\begin{array}{l}\text { Cortical dysplasia, complex, with } \\
\text { other brain malformations } 3 \\
\text { (CDCBM3), \#615 } 411\end{array}$ & $\begin{array}{l}\text { Microcephaly, early-onset epilepsy and various } \\
\text { malformations of cortical development, including } \\
\text { agyria, posterior or frontal pachygyria, subcortical } \\
\text { band heterotopia and thin corpus callosum; severe } \\
\text { developmental delay, spastic paraplegia, persistent } \\
\text { hyperplastic primary vitreous and microphthalmia }\end{array}$ & $5 q 12.1$ & $A D$ & $\begin{array}{l}\text { Missense variants } \\
\text { Kinesin motor domain }\end{array}$ \\
\hline
\end{tabular}

Susceptibility loci are not included.

OMIM online mendelian inheritance of man, www.omim.org

$A D$, autosomal dominant; $A R$, autosomal recessive; CNV, copy number variant; IUGR, intrauterine growth retardation; PX, phox homology; XLR, X-linked recessive.

syndromic hydrocephalus. KIF4A was recently proposed as a candidate gene for hydrocephalus. ${ }^{11}$

KIFs are involved in neuronal branching, and microtubule depolarisation, operated by KIF2A M-kinesin, was suggested to suppress collateral branch extension during brain development, leading to anomalies of cortical development, including agyria and pachygyria, subcortical band heterotopia and corpus callosum anomalies. ${ }^{12}$

Functional disruption of KIF genes in knockout mice often results in embryonic lethality, for example, for Kif18A, Kif10, Kif $3 A$, Kif $3 B$ and $K$ if $5 B,{ }^{13-17}$ highlighting the importance of kinesins in embryonic and foetal development. A study on KIF16B demonstrated that microtubule-based trafficking is responsible for early development and stem cell survival. ${ }^{18}$ KIF26B is essential in kidney development, contributing to the adhesion of mesenchymal cells to the ureteric bud. ${ }^{3}$ KIF26A was suggested to play a role in enteric nervous system development, because knockout mice develop a megacolon and enteric nerve hypoplasia, ${ }^{19}$ and to negatively regulate nociceptive sensation. ${ }^{20}$

A significant number of KIFs play a prominent role in ciliogenesis and cilia function. They regulate cilia length, ciliary assembly/disassembly and can have motile cilia-specific functions. $^{21}$ Some KIFs, specifically found in primary cilia (PC), regulate the length of the axoneme and its disassembly when re-entering the cell cycle.

KIF7, also a key component of the Hedgehog signalling pathway, is responsible for cilia length regulation through suppression of microtubule polymerisation. ${ }^{7}$ KIF7 variants

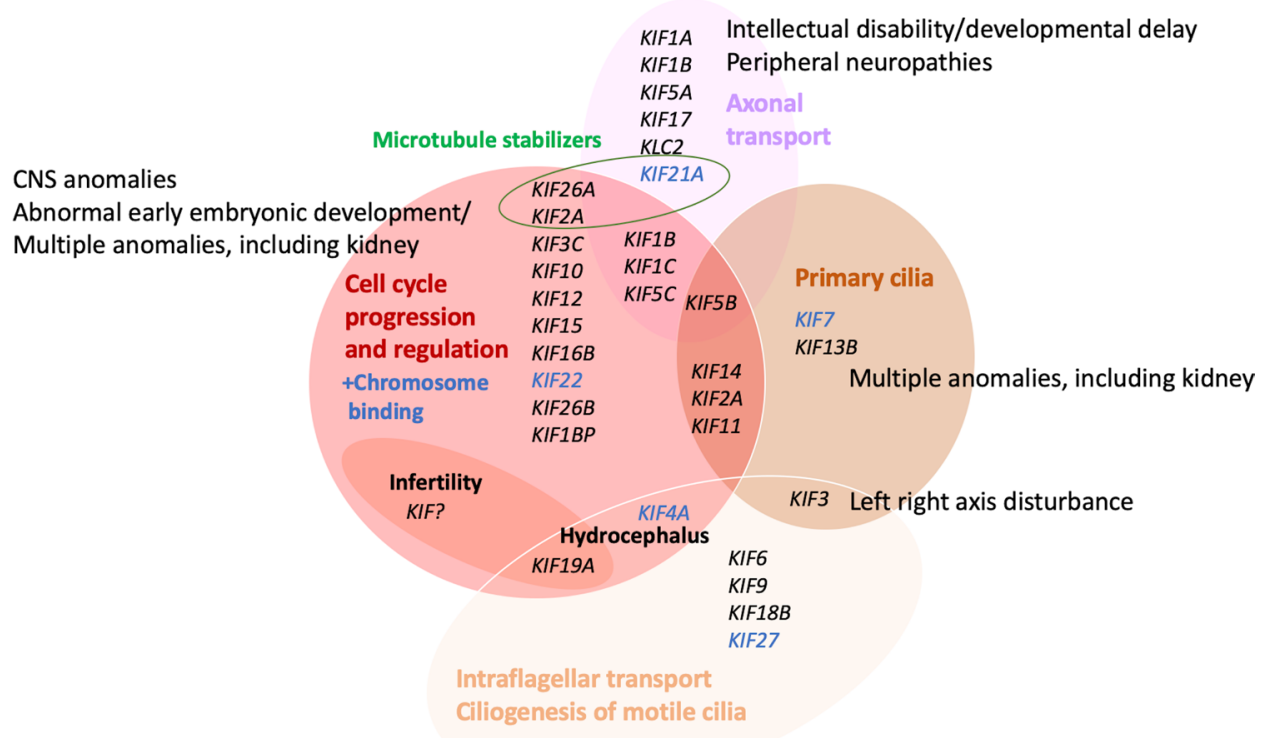

Figure 2 Assignment and clustering of KIF genes to various functions and relation to birth defect or monogenic phenotype groups. Detailed phenotypes are shown in tables 1 and 3. Cancer and multifactorial conditions are not included. CNS, central nervous system. 
cause hydrolethalus, acrocallosal, and Joubert and Al-GazaliBakalinova syndromes. ${ }^{22} \mathrm{Kif} 2 \mathrm{~A}$ knockout mice have severe brain defects, and KIF2A variants in humans lead to microcephaly because of cell-cycle delay in cellular progenitors resulting from cilia disassembly defects. KIF24, belonging to the same kinesin 13 family, plays a role in both microtubule depolymerising activity and regulation of the early steps of ciliogenesis. Other PC-related KIFs recently identified are KIF5B, KIF1C and KIF13B, and a potential role in cilia was hypothesised for KIF11 and KIF14.

KIF3 protein complex (KIF3A-KIF3B-KAP3 heterotetramer) is a molecular motor necessary for intraflagellar transport (IFT) but is also involved in ciliogenesis of motile cilia. Kif $3 a$-knockout or Kif3b-knockout mice are prenatally lethal, exhibiting anomalies similar to ciliopathy phenotypes, including the disturbance of left-right body determination. ${ }^{3}$

KIF19A is localised at the tip of motile cilia and performs motor and microtubule-depolymerising activities during IFT. Kif19a-knockout mice present with hydrocephalus and female infertility, common signs in ciliary defects, due to abnormally elongated cilia with altered motility, not able to generate proper fluid flow. ${ }^{9}$

Further KIFs, which may have specific roles in motile cilia, are KIF27, KIF9, KIF6 and KIF18B. Regarding the involvement of numerous KIFs in cilia-related processes, it is not surprising that many disorders caused by variants affecting KIF gene function are presenting with anomalies reminiscent of ciliopathies.

Kinesin motors have a fundamental role in neuronal function, as they are responsible for the transport of synaptic vesicle precursors and transmitter receptors along axons and dendrites from the neuron body. ${ }^{3}$ Molecular motor activity as for KIF1A, KIF5 and KIF17 is important for higher brain functions, such as learning and memory through regulation of synaptic transmission. ${ }^{5}$ Dysfunction can be associated with intellectual disability and global developmental delay (table 1).

Impaired function can also result in peripheral neuropathies (KIF5A, KLC2, KIF1A and KIF1B) and ocular motility disorders $(K L C 2 \text { and KIF21A })^{2324}$ when axon elongation in the peripheral nervous system and optic nerve is affected. KIF5A variants are associated with epileptic phenotypes both in humans and mice ${ }^{25}$ because the transport of neurotransmitter receptors is disturbed and inhibitory regulation is altered.

Due to their role in cell-cycle regulation, kinesins are important in male spermatogenesis and female oogenesis. They are involved in all steps of spermatogenesis ${ }^{26}$ and, based on previous animal studies, they may represent a potential target to treat male infertility. In female meiosis, 13 KIF genes were studied in animal models. There is some evidence that kinesin expression is vulnerable to maternal ageing and environmental factors, such as oocyte cryopreservation and alcohol consumption. It may be promising to expand research in this field in order to clarify the mechanisms and factors contributing to oocyte quality decline. ${ }^{27}$

Many kinesins were extensively studied in the fields of cancer development, progression and therapy. Deregulation of the mitotic kinesins by both overexpression and decreased expression causes cancer progression or can be a prognostic marker in various tumours. ${ }^{28}$ The cell-permeable small-molecule mitotic inhibitor monastrol was discovered in $1999^{29}$ and was shown to arrest cells in mitosis by specifically inhibiting KIF11, a kinesin important for spindle bipolarity. The bipolar mitotic spindle is replaced by a monoastral microtubule array surrounded by a ring of chromosomes, which gave the inhibitor its name. The mitotic spindle is now a well-known target of chemotherapy, and inhibitors of the mitotic kinesins KIF11, KIF10 and KIF1C are being studied for this purpose. ${ }^{28} 30$ The redundancy of some kinesins allows them to escape pharmacological inhibition. For example, in the absence of KIF10, KIF15 is able to replace all of its essential functions in spindle assembly. Cilia-related KIF7, KIF13B and KIF27 are involved in SHh signalling and may be a future target in cancer research. ${ }^{28}$

Some kinesins confer susceptibility to a range of multifactorial, metabolic and neurodegenerative conditions. KIF13B contributes to the enhancement of endocytosis of low-density lipoprotein $(\mathrm{LDL})$ receptor-related protein 1 that is involved in the recognition and internalisation of LDL and factor VIII. Kif13bknockout mice have hypercholesterolaemia and higher factor VIII serum levels. ${ }^{5}$ KIF12 is implicated in the pathogenesis of type 2 diabetes, protecting pancreatic $\beta$ cells from the oxidative stress caused by nutritional excess. ${ }^{5}$ Variants in KIF1B or KIF $21 B$ confer susceptibility to multiple sclerosis (OMIM \%612596, \#126200). ${ }^{31}{ }^{32}$ KIF5A was associated with Amyotrophic lateral sclerosis (OMIM \#617921). ${ }^{33}$ KIF3 complex and KIF17 were recently uncovered to be involved in schizophrenia. ${ }^{345}$ Further studies, however, are needed to clarify the precise role of KIFs in neurodegenerative processes and psychiatric conditions.

\section{KIF14 -RELATED BIRTH DEFECTS: LESSONS LEARNT}

Advances in next-generation sequencing technologies have revolutionised our understanding of Mendelian disorders, including birth defect phenotypes, by sequencing the coding genome (exome) or entire genome at an unprecedented resolution in a comparably short time span. The technology has been extensively used for gene identification approaches in research for many years, enabling unparalleled genotype-phenotype correlations and the definition of novel pathways of related genes and disorders at an accelerated pace, traditionally focusing on postnatal disorders. Filges and Friedman ${ }^{36}$ postulated that a number of novel disease genes causing birth defects could be identifiable through the investigation of lethal foetal phenotypes since they would represent the extreme end of allelic milder and viable postnatal phenotypes with less specific or recognisable anomaly patterns. Based on embryonically or perinatally lethal mouse models (www.informatics.jax.org and www.dmdd.org.uk), it is estimated that knockout variants in about $30 \%$ of human protein coding genes may present with a phenotype of early lethality. The identification of KIF14 loss of function variants in fetuses with a lethal multiple congenital anomaly syndrome and the subsequent description of the allelic postnatal viable phenotype and further functional characterisation of KIF14 in developmental processes are recent examples of how to study those embryonic lethal phenotypes in order to understand the role of genes for which little to nothing is known.

Filges et al identified autosomal recessive compound heterozygous loss of function variants in KIF14 using family-based exome sequencing in a recurrent severe lethal phenotype (OMIM \#616258). It was the first human phenotype reported due to variants in the human KIF14 gene (figure 3). ${ }^{37}$ The two affected siblings presented with intrauterine growth retardation (IUGR), oligohydramnios, severe microcephaly, renal cystic dysplasia or agenesis, genital tract malformations (uterine hypoplasia and vaginal atresia), as well as cerebral and cerebellar hypoplasias with partial or total agenesis of the vermis, arhinencephaly, agenesis of occipital lobes/corpus callosum at second trimester ultrasound scan. Cross-species comparison to the laggard spontaneous mice mutant, characterised by homozygous variants of the Kif14 gene, ${ }^{38}$ confirmed a phenotypical overlap. An increased 


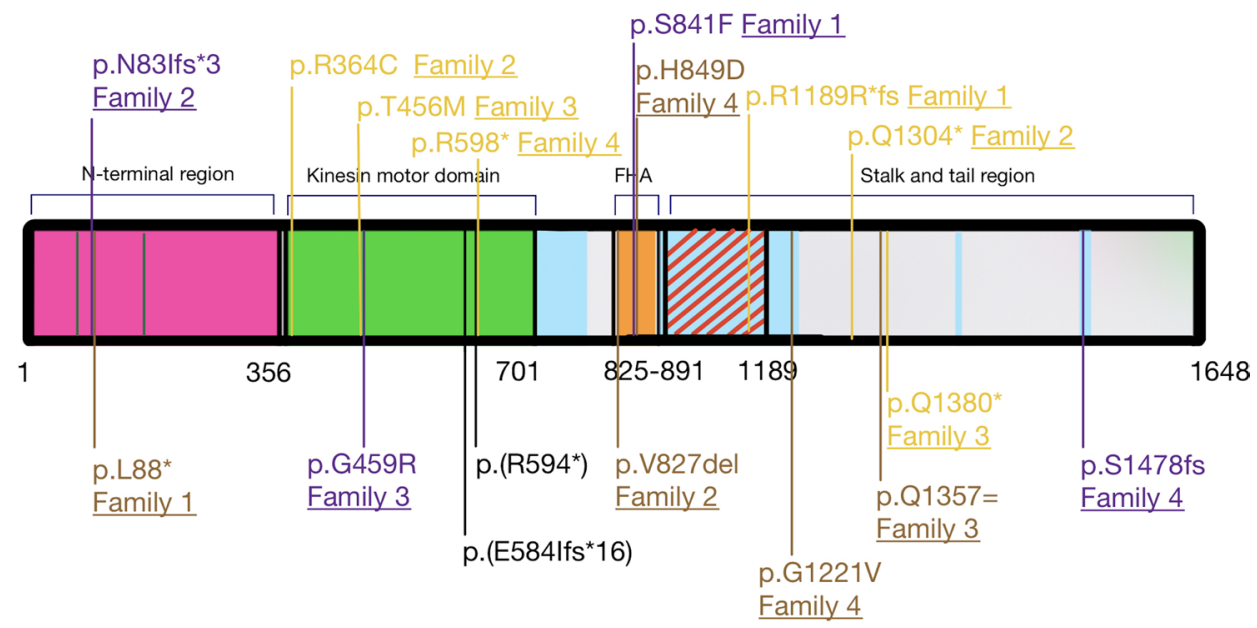

\section{- = Filges et al. $\quad-$ Moawia et al. $\quad-$ Makrythanasis et al. $\quad=$ Reilly et al.}

Figure 3 Structure of KIF14 and summary of all published KIF14 variants affecting function. ${ }^{10374142}$ The N-terminal region (aa 1-356) is important for its interactions with PRC1 and the protein's localisation at the central spindle and midbody; the kinesin motor domain (aa 358-701) is responsible for the microtubule-dependent ATPase activity; the FHA domain (aa 825-891); stalk and tail region (aa 891-1648) are necessary for the interaction with the protein CRIK (aa 901-1189, red diagonal lines). There are four additional coiled-coil domains (light blue-coloured areas). ${ }^{61}$ FHA, forkhead associated. aa, amino acid.

number of binucleated cells in the tissue histology of the two fetuses were in concordance with the key role of KIF14 during mitosis participating in chromosomes' congression and alignment, as well as in cytokinesis ${ }^{39}$ and the observation of binucleated cells as a consequence of failed cytokinesis in mammalian KIF14 knockdown cells. During cytokinesis, PRC1 localises KIF14 at the central spindle and midbody, which in turn recruits citron rho-interacting kinase (CIT) to the midbody. CIT, in turn, acts as a negative regulator of KIF14 activity. Knockdown of KIF14 in mammalian cells results in impaired localisation of CIT during mitosis. ${ }^{40}$

Filges et al pointed out that KIF14 should be considered a candidate gene for viable postnatal phenotypes, including isolated microcephaly. ${ }^{34}$ Additional individuals with autosomal recessive variants in KIF14 and isolated primary microcephaly were then described ${ }^{9142}$ (table 2).

Impaired cytokinesis, increased apoptosis and reduced cell motility were confirmed in cells from the described patients, pointing to a new cellular pathway in the pathogenesis of microcephaly. ${ }^{43}$ Apart from one case with small kidneys with increased echogenicity, none of these 18 patients had associated kidney anomalies. However, a targeted exome sequencing study in 204 unrelated patients with congenital anomalies of the kidney and urinary tract (CAKUT) reported two more cases of renal anomalies, bilateral hypoplasia or agenesis, caused by KIF14 variants. ${ }^{44}$ Further nine cases had an associated renal phenotype, which ranged from bilateral renal agenesis to cystic or non-cystic renal hypodysplasia. ${ }^{42}$ Table 2 and figure 3 summarise KIF14 variants and the associated phenotypes. Loss of function variants more likely lead to multiple congenital anomalies, while hypomorphic variants result in a milder phenotype without renal involvement, although phenotype-genotype correlations remain preliminary for the time being.

The phenotypical spectrum ranging from isolated primary microcephaly to congenital anomalies reminiscent of ciliopathy phenotypes suggested a complex role for KIF14 in developmental processes and raised a number of questions about the relationship between its established role in cell division and its possible function in ciliary pathways. Functional studies of absent KIF14 protein in the development of human foetal tissues and mutant zebrafish provided evidence for similarities and differences between mitotic events occurring during proliferation in the development of both brain and kidney. ${ }^{42}$ The observation that KIF14-stained midbodies accumulate within the lumen of the branch tips of ureteric buds in human foetal kidneys provided a key clue to better understand the mechanism through which the loss of KIF14 affects both brain and kidney development in humans. It was previously demonstrated that the secretion and accumulation of midbody remnants in the cerebrospinal fluid in mice during the early stages of brain development correspond to the amplification of neural progenitors. ${ }^{45}$ Kif14 mutant zebrafish phenotypes supported the hypothesis of a potential role for KIF14 in cilia. In vitro and in vivo analyses suggested that loss of kif14 causes ciliary anomalies through an accumulation of mitotic cells in ciliated tissues but failed to establish a direct functional link. ${ }^{2142}$ Further mechanisms remain to be elucidated. Overexpression of KIF14 in various types of tumours was suggested to be a possible prognostic marker and a potential target for therapeutic purposes. ${ }^{46}$

\section{KINESINOPATHIES IN BIRTH DEFECT PHENOTYPES: RECURRENT THEMES}

In the last few years, an increasing number of variants in KIF genes were described to cause isolated as well as multiple congenital anomalies. There is a huge variability of phenotypes caused by variants even within the same gene. However, we can identify recurrent clinical signs that should alert the clinician to suspect a KIF gene-related disorder and the molecular geneticist to include KIF genes in multigene-panel and genome-wide sequencing approaches. This will become particularly relevant in prenatal and perinatal medicine, which focuses on the detection of structural anomalies in the fetus and the newborn by using ultrasound and MRI or autopsy when the outcome is lethal. We have summarised the predominant and recurrent structural anomalies in kinesinopathies reported so far that would likely 
Table 2 Summary of phenotypes and genotypes of KIF14 2263031

\begin{tabular}{|c|c|c|c|c|c|c|c|}
\hline Family & $\begin{array}{l}\text { Individuals affected } \\
\text { (n) }\end{array}$ & Consanguinity & CNS phenotype & $\begin{array}{l}\text { Kidney } \\
\text { phenotype }\end{array}$ & $\begin{array}{l}\text { Prenatal lethal } \\
\text { wGA }\end{array}$ & KIF14 sequence variant & $\begin{array}{l}\text { Functional } \\
\text { domain }\end{array}$ \\
\hline Filges et $a \beta^{37}$ & 2 & - & $\begin{array}{l}\text { Microcephaly, agenesis } \\
\text { of occipital lobes, CC } \\
\text { and vermis }\end{array}$ & BRA, RHD & $21+4 ; 18+5$ & $\begin{array}{l}\text { c.1750_1751del, c.1780A>T } \\
\text { p.Glu584llefs*16, } \\
\text { p.Arg594* }\end{array}$ & Motor domain \\
\hline $\begin{array}{l}\text { Moawia et al }{ }^{10} \\
\text { Family } 1\end{array}$ & 3 & + & $\begin{array}{l}\text { Microcephaly with } \\
\text { simplified gyral pattern }\end{array}$ & - & - & $\begin{array}{l}\text { c. } 263 \mathrm{~A}>\mathrm{T} \\
\text { p.Leu88*/ p.Gly58 } \\
\text { Leu181del }\end{array}$ & PRC1 binding \\
\hline $\begin{array}{l}\text { Moawia et al }{ }^{10} \\
\text { Family } 2\end{array}$ & 2 & + & $\begin{array}{l}\text { Microcephaly with } \\
\text { simplified gyral pattern }\end{array}$ & - & - & $\begin{array}{l}\text { c.2480_2482delTTG } \\
\text { p.Val827del }\end{array}$ & FHA domain \\
\hline $\begin{array}{l}\text { Moawia et al } \\
\text { Family } 3\end{array}$ & 3 & + & Microcephaly & - & - & $\begin{array}{l}\text { c. } 4071 \mathrm{G}>A \\
\text { p.GIn1357=/ } \\
\text { p.Leu1296Trpfs*46 }\end{array}$ & C-terminal tail \\
\hline $\begin{array}{l}\text { Moawia et al }{ }^{10} \\
\text { Family } 4\end{array}$ & 2 & - & $\begin{array}{l}\text { Microcephaly, } \\
\text { lissencephaly CC } \\
\text { agenesis }\end{array}$ & $\begin{array}{l}\text { Small kidneys, } \\
\text { increased } \\
\text { echogenicity }\end{array}$ & 24 & $\begin{array}{l}\text { c. } 2545 C>G, \text { c.3662G>T } \\
\text { p.His849Asp, p.Gly1221Val/ } \\
\text { p.Gly1221 Lys1296delinsVal }\end{array}$ & $\begin{array}{l}\text { FHA domain } \\
\text { C-terminal tail }\end{array}$ \\
\hline $\begin{array}{l}\text { Makrythanasis et } \\
\text { al }^{41} \\
\text { Family } 1\end{array}$ & 2 & + & Intellectual disability & - & - & $\begin{array}{l}\text { c. } 2522 \mathrm{C}>\mathrm{T} \\
\text { p.Ser841Phe }\end{array}$ & FHA domain \\
\hline $\begin{array}{l}\text { Makrythanasis et } \\
\text { al }{ }^{41} \\
\text { Family } 2\end{array}$ & 2 & + & $\begin{array}{l}\text { Microcephaly, optic } \\
\text { atrophy, ASD }\end{array}$ & - & - & $\begin{array}{l}\text { c.246delT } \\
\text { p.Asn83llefs } 3\end{array}$ & PRC1 binding \\
\hline $\begin{array}{l}\text { Makrythanasis et } \\
\text { al }{ }^{41} \\
\text { Family } 3\end{array}$ & 2 & + & $\begin{array}{l}\text { Microlissen-cephaly } \\
\text { frontal cerebral atrophy, } \\
\text { partial agenesis of CC }\end{array}$ & - & - & $\begin{array}{l}\text { c.1375G >A } \\
\text { p.Gly459Arg }\end{array}$ & Motor domain \\
\hline $\begin{array}{l}\text { Makrythanasis et } \\
\text { al }^{41} \\
\text { Family } 4\end{array}$ & 2 & + & Microcephaly & - & $15 ; 17$ & $\begin{array}{l}\text { c.4432delA } \\
\text { p.Ser1478fs }\end{array}$ & C-terminal tail \\
\hline $\begin{array}{l}\text { Reilly et } a /^{42} \\
\text { Family } 1\end{array}$ & 1 & - & $\begin{array}{l}\text { Microcephaly, CC } \\
\text { agenesis, brainstem } \\
\text { hypoplasia }\end{array}$ & Cystic RHD & 18 & $\begin{array}{l}\text { c.35672?_4072+?del } \\
\text { p.Arg1189Argfs*9 }\end{array}$ & C-terminal tail \\
\hline $\begin{array}{l}\text { Reilly et al }{ }^{42} \\
\text { Family } 2\end{array}$ & 3 & - & $\begin{array}{l}\text { Microcephaly, } \\
\text { holoprosencephaly }\end{array}$ & $\mathrm{BRA}^{2}, \mathrm{RHD}^{1}$ & $33 ; 37+1 ; 18+3$ & $\begin{array}{l}\text { c. } 3910 \text { C>T, c. } 1090 \text { C>T } \\
\text { p.Gln1304*, p.Arg364Cys }\end{array}$ & $\begin{array}{l}\text { C-terminal tail } \\
\text { Motor domain }\end{array}$ \\
\hline $\begin{array}{l}\text { Reilly et al }{ }^{42} \\
\text { Family } 3\end{array}$ & 3 & - & $\begin{array}{l}\text { Microcephaly, CC } \\
\text { agenesis, brainstem } \\
\text { hypoplasia }\end{array}$ & Cystic RHD & $24 ; 20+3 ; 18$ & $\begin{array}{l}\text { c. } 1367 C>T, \text { c. } 4138 C>T \\
\text { p.Thr456Met, p.Gln1380* }\end{array}$ & $\begin{array}{l}\text { C-terminal tail } \\
\text { Motor domain }\end{array}$ \\
\hline $\begin{array}{l}\text { Reilly et al }{ }^{42} \\
\text { Family } 4\end{array}$ & 4 & - & Microlissencephaly & $\begin{array}{l}\text { Cystic RHD², } \\
\text { RHD }^{1}, \text { BRA }^{1}\end{array}$ & $\begin{array}{l}27+4 ; 17+4 ; \\
21+2 ; 23\end{array}$ & $\begin{array}{l}\text { c. } 1792 C>T \\
\text { p.Arg598* }\end{array}$ & Motor domain \\
\hline
\end{tabular}

ASD, autism spectrum disorder; BRA, bilateral renal agenesis; CC, corpus callosum; CNS, central nervous system; FHA, forkhead associated; PRC1, protein regulating cytokinesis 1 ; RHD, renal hypodysplasia; wGA, weeks gestational age

become apparent during the foetal period in table 3 and the syndromic disorders in table 1.

Consistent with the kinesins' role in the development of the central nervous system (CNS), brain anomalies of various degrees are a frequent clinical sign, particularly microcephaly, but include lissencephaly, polymicrogyria, thinned or agenesis of the corpus callosum, arhinencephaly, cerebral hypoplasia or atrophy, cerebellar hypoplasia or atrophy, brainstem hypoplasia and a molar tooth sign on brain imaging. ${ }^{12} 22374447-51$

Primary microcephaly can be detected prenatally or at birth $^{122247485051}$ and can present as an isolated or syndromic condition as, for example, caused by variants in $K I F 14^{9}$ or in KIF11 (microcephaly with or without chorioretinopathy, lymphoedema or mental retardation; OMIM \#152950). ${ }^{48}$

KIF7 variants were related to macrocephaly in the presence of congenital hydrocephalus (hydrolethalus syndrome LS2, OMIM \# 614120). Isolated hydrocephalus was reported for KIF4A in a single case. ${ }^{11}$

Foetal akinesia and arthrogryposis $\left(\right.$ KIF5 $C^{12}, \mathrm{KIF}^{3} 4^{34}$ and KIF $26 B^{50}$ ) are likely secondary to the neurological compromise of the fetus but can also appear as an early sign of abnormal CNS development, which should prompt specialist CNS sonographic and MRI evaluation of the fetus.

Further anomalies of the limbs include camptodactyly $\left(K I F 26 B^{50}\right)$, clubfoot $\left(K I F 1 A^{51}\right)$, rocker-bottom feet $\left(K I F 26 B^{50}\right)$ and congenital lymphoedema of the limbs (dorsa of feet, lower extremities and, rarely, hands) in cases with KIF11 gene mutations. ${ }^{48}$ In particular, KIF7 gene variants have been related to various anomalies of the hands (tapered fingers, fifth finger clinodactyly, brachydactyly, preaxial or postaxial polydactyly, bifid terminal phalanges of the thumbs, spindle-shaped fingers, clinodactyly and soft tissue webbing) and feet (toe syndactyly, preaxial or postaxial polydactyly, and duplicated halluces). ${ }^{22}$

CAKUT and genital anomalies are reported in various kinesinopathies including renal agenesis or hypoplasia (KIF14 ${ }^{37}$ and $K I F 12^{52}$ ), ureteral hypoplasia $\left(K I F 14^{37}\right)$, congenital megabladder $\left(K I F 12^{52}\right)$ and vesicoureteral reflux $\left(K I F 12^{52}\right)$, uterine hypoplasia and vaginal atresia $\left(K I F 14^{37}\right)$ and hypospadias and chordae $\left(\right.$ KIF16B $\left.{ }^{49}\right)$.

IUGR is recurrently detected $\left(\mathrm{KIFSC}^{12}, \mathrm{KIF}^{3} 4^{37}, \mathrm{KIF}^{5} 0^{53}\right.$, $K I F 15^{54}$ and $K I F 2 A^{12}$ ) and is particularly relevant when occurring simultaneously with one of the other recurrent clinical 
Table 3 KIF gene-related structural congenital anomalies recurrently described in prenatal phenotypes

\begin{tabular}{|c|c|c|c|c|c|c|c|c|c|c|c|c|c|}
\hline \multirow{2}{*}{\multicolumn{2}{|c|}{ Structural congenital anomaly }} & \multirow{3}{*}{$\begin{array}{l}\text { Kinesin } 1 \\
\text { KIF5C } \\
+\end{array}$} & \multicolumn{3}{|c|}{ Kinesin 3} & \multicolumn{2}{|c|}{ Kinesin 4} & \multirow{3}{*}{$\begin{array}{l}\text { Kinesin } 5 \\
\text { KIF11 } \\
+\end{array}$} & \multirow{3}{*}{$\begin{array}{l}\text { Kinesin } 7 \\
\text { KIF10 } \\
++\end{array}$} & \multirow{3}{*}{$\begin{array}{l}\text { Kinesin } 11 \\
\text { KIF26B } \\
+\end{array}$} & \multicolumn{2}{|c|}{ Kinesin 12} & \multirow{3}{*}{$\begin{array}{l}\text { Kinesin } 13 \\
\text { KIF2A } \\
++\end{array}$} \\
\hline & & & \multirow{2}{*}{$\begin{array}{l}\text { KIF1A } \\
+\end{array}$} & \multirow{2}{*}{$\begin{array}{l}\text { KIF14 } \\
+\end{array}$} & \multirow{2}{*}{$\begin{array}{l}\text { KIF16B } \\
-\end{array}$} & \multirow{2}{*}{$\begin{array}{l}\text { KIF7 } \\
-\end{array}$} & \multirow{2}{*}{$\begin{array}{l}\text { KIF4A } \\
-\end{array}$} & & & & \multirow{2}{*}{$\begin{array}{l}\text { KIF12 } \\
-\end{array}$} & \multirow{2}{*}{$\begin{array}{l}\text { KIF15 } \\
+\end{array}$} & \\
\hline CNS anomalies & Microcephaly & & & & & & & & & & & & \\
\hline & Lissencephaly & + & - & + & - & - & - & + & + & - & - & - & + \\
\hline & Thinned CC & + & - & - & + & - & - & - & - & + & - & - & - \\
\hline & Agenesis of CC & - & - & + & - & + & - & - & + & - & - & - & - \\
\hline & Arhinencephaly & - & - & + & - & + & - & - & - & - & - & - & - \\
\hline & Cerebral hypoplasia & - & - & + & - & - & - & - & - & - & - & - & - \\
\hline & Cerebral atrophy & - & + & - & - & + & - & - & - & - & - & - & - \\
\hline & $\begin{array}{l}\text { Cerebellar } \\
\text { hypoplasia }\end{array}$ & - & - & + & - & - & - & - & + & + & - & - & - \\
\hline & Cerebellar atrophy & - & + & - & - & - & - & - & - & - & - & - & - \\
\hline & $\begin{array}{l}\text { Brainstem } \\
\text { hypoplasia }\end{array}$ & - & - & - & - & - & - & - & - & + & - & - & - \\
\hline & Molar tooth sign & - & - & - & - & + & - & - & - & - & - & - & - \\
\hline & $\begin{array}{l}\text { Macrocephaly/ } \\
\text { hydrocephalus }\end{array}$ & - & - & - & - & + & + & - & - & - & - & - & - \\
\hline \multirow[t]{2}{*}{ Limbs } & Hand anomalies & _- & - & + & - & + & - & + & - & + & - & - & - \\
\hline & Feet anomalies & - & + & - & - & + & - & + & - & + & - & - & - \\
\hline \multicolumn{2}{|l|}{ CAKUT } & - & - & + & - & - & - & - & - & - & + & - & - \\
\hline \multicolumn{2}{|c|}{ Genital tract anomalies } & - & - & + & + & - & - & - & - & - & - & - & - \\
\hline \multicolumn{2}{|l|}{ IUGR } & + & + & + & - & - & - & - & + & - & - & + & + \\
\hline
\end{tabular}

' + ' indicates that the anomaly is described in the literature at least in one case, while ' - ' indicates that an anomaly was never reported in association with a variant in the specific KIF gene to date. Clinical case descriptions and the respective references are appended in online supplementary material, table 3.

CAKUT, congenital anomalies of the kidney and urinary tract; CC, Corpus callosum; CNS, central nervous system; IUGR, intrauterine growth restriction.

signs, indicating a potential syndromic KIF-related disorder. Oligohydramnios or polyhydramnios is most likely secondary to a primary organ anomaly.

There are a few kinesinopathy syndromes that have been specifically reported to be lethal, such as the ciliary phenotype (OMIM \#616258), caused by variants in KIF14 ${ }^{34}$, and hydrolethalus syndrome (OMIM \#614120), caused by variants in KIF7. ${ }^{22}$ However, lethality is usually closely related to the specific major anomalies, and it can be hypothesised that such a lethal phenotype will exist for all KIF gene-related disorders.

Developmental delay, intellectual disability, seizures, and sensory and motor disturbances of the peripheral nervous system, as well as eye anomalies, such as microphthalmy, optic nerve pallor, fibrosis of extraocular muscles and chorioretinopathy, will escape detection in the foetal period but are reported in postnatal patients.

\section{KINESIN PATHWAYS IN BIRTH DEFECTS}

Functional studies of kinesins in birth defects are still sparse, and little is known about their networks and pathways. In order to improve our understanding, we used the Ingenuity Pathway Analysis (IPA Qiagen, Redwood City, California, USA) to visualise and analyse the connections between the 13 kinesin motor proteins associated with structural congenital anomalies (KIF5C, KIF1A, KIF1BP, KIF14, KIF16B, KIF7, KIF4A, KIF11, KIF10, KIF26B, KIF12, KIF15 and KIF2A) and in up to 10 of each of their most significant downstream proteins. The connections are defined as protein-protein interactions, activation, regulation of binding, expression, localisation, phosphorylation, protein-RNA interactions, molecular cleavage, ubiquitination, protein-DNA interactions, inhibition, translocation and transcription. Figure 3 displays the results. We used the software Gephy ${ }^{55}$ to look for all possible interactions between all proteins of the network and also used the IPA data to retrieve the canonical pathways involved. Figure 4 and online supplementary material, table
4, summarise the results. KIF7, KIF14 and KIF12 are located within the same network, and because of multiple connections between themselves and their downstream proteins, it is not surprising that they are all involved in kidney anomalies. IPA data are based on current publications and are therefore subject to bias because proteins that are most interconnected are also most probably those that have been more extensively studied. However, we consider the KIF genes coding for proteins seeming less important within the network to be strong candidates for future studies of human developmental disorders.

\section{CLOSING REMARKS AND FUTURE PERSPECTIVES}

Novel KIF genes are increasingly identified, and there is a growing body of literature demonstrating the impact of kinesin dysfunction in human disease. We propose to introduce the term kinesinopathies for conditions caused by variants in KIF genes, since recurrent and common functional and phenotypical themes can be observed. In analogy to ciliopathies ${ }^{56}$ and rasopathies, ${ }^{57}$ the delineation of the clinical, genetic and functional hallmarks of kinesinopathies will be important to better recognise these conditions, to understand the pathomechanisms and to ultimately improve the clinical management of the patients. Previously, the unified view of the phenotype characteristics of ciliary dysfunction allowed a tremendous increase in awareness, both in clinic and research, and the further identification of yet unrecognised ciliary disorders and the genes and proteins involved in their pathogenesis. ${ }^{56}$

Remarkable progress was achieved in assigning function to kinesins through their study in isolated and multiple congenital anomaly phenotypes. They are one large superfamily of molecular motors out of three (kinesins, dyneins and myosins), which is of key importance in several fundamental cellular processes using microtubules as rails for directional anterograde intracellular transport, including its regulation and modulating signal transduction. ${ }^{5}$ Kinesin motors are most important for the 


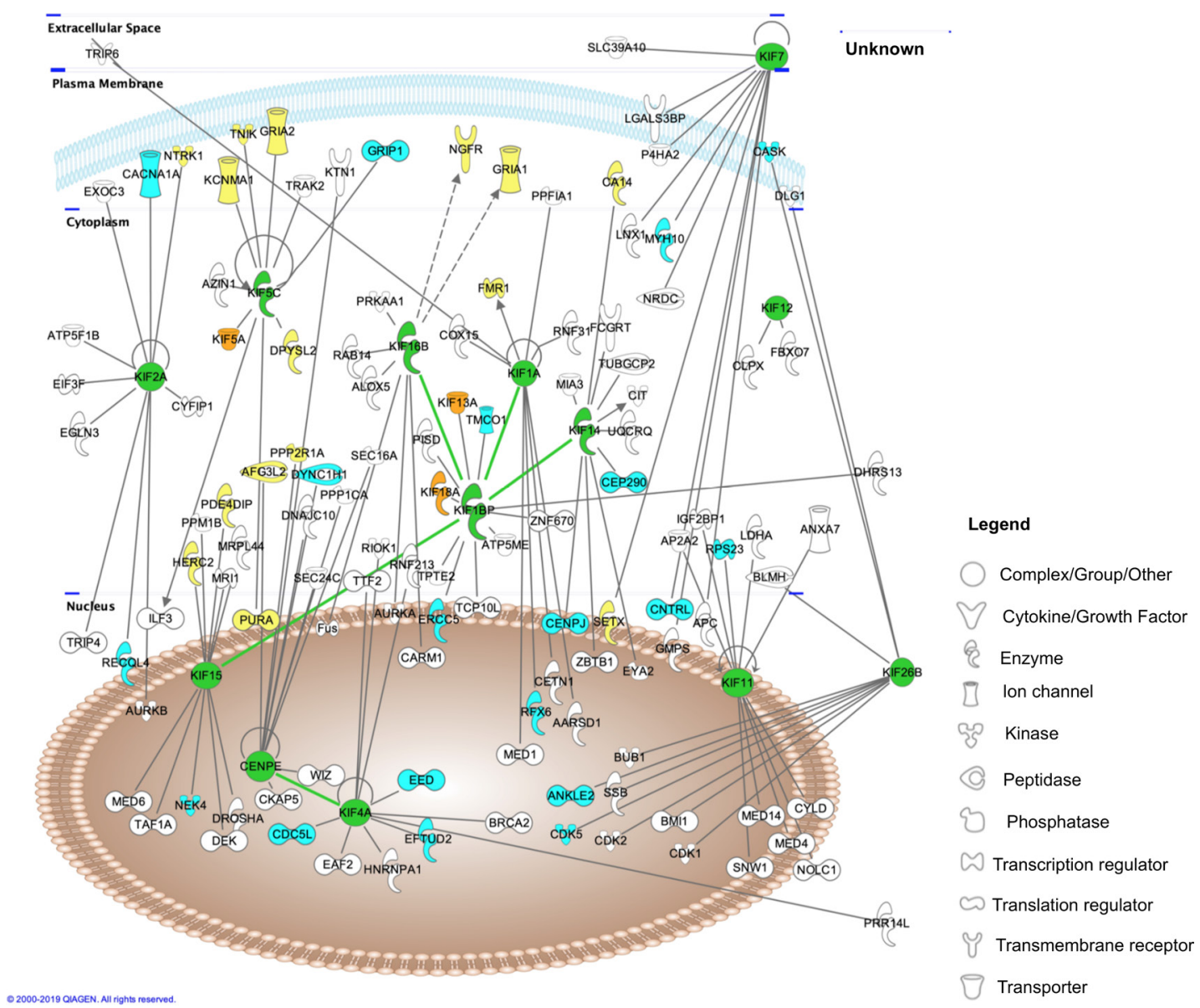

Figure 4 IPA of the 13 kinesins known to be involved in birth defects with respect to their position in the cell. Proteins displayed on the right side of the figure, below the tag 'other', are those for which no subcellular location is known. Birth defect-related kinesins and their connection with each other are highlighted in green. Light blue-coloured downstream proteins are those which are known to cause birth defects when altered. Yellow-coloured proteins are those involved in neurological disorders overlapping with the clinical features of kinesinopathies. The legend of the biological function associated with every molecule is displayed on the right. Path Designer by IPA was used for the figure design. IPA, Ingenuity Pathway Analysis.

movement of chromosomes along the spindles during chromosome segregation, regulation of spindle formation, cell division and cytokinesis. These essential and broad cellular functions are critical for many physiological processes such as neuronal function and survival, some ciliary functions and ciliogenesis, determination of the left/right asymmetry of our body and regulation of organogenesis, thus explaining the impact and emerging recognition of kinesins in embryonic and foetal development. Defects can result in neuropathies, higher brain functions and structural brain anomalies. Multiple congenital anomalies, including the kidney and urinary tract and limb anomalies, are repeatedly reported. Microcephaly, which is usually not associated with genes implicated in specific ciliary mechanisms, and CNS anomalies are the most recurrent clinical signs in both the prenatal and postnatal phenotypes described so far. The discovery of the implication of KIF14 in microcephaly further suggested a possible novel role of other microcephaly proteins in cytokinesis. A number of syndromic kinesinopathies present, however, with phenotype patterns reminiscent of ciliopathies. So far, however, a direct functional impact was confirmed in only a few and could not be demonstrated, for example, for KIF14, despite an overlapping clinical pattern. In turn, ciliopathies are a clinically and genetically heterogeneous group of conditions themselves. Studying tissue and cell type-specific function and expression may help to further define the specific defects related to the individual aberrant kinesin.

The pleiotropic nature of human kinesinopathies, however, is just emerging, but their study promises to provide important insights into human developmental pathways. Seemingly unrelated clinical entities are highlighting a common theme. In a relatively short time span, monogenic KIF-related disorders were identified to present with often severe and lethal antenatal anomalies, with multiple or isolated congenital anomalies, neurodevelopmental and neurological disorders, or an increased susceptibility to multifactorial conditions. We focused on the emerging role of kinesins in structural congenital anomalies because, as illustrated for the KIF14 gene, great potential to decipher allelic viable phenotypes and developmental pathways lies in the study of these human knockout phenotypes at the severe end of the phenotypical spectrum. Knockout variants in about $30 \%$ of human protein coding genes in our genome may present with a phenotype of early lethality, and KIF genes seem to play an important role in such fundamental processes of human development. Identifying and characterising the variants, genes and phenotypes will extend our knowledge on early human development and pathomechanisms, and will ultimately also improve the clinical utility of genome-wide sequencing approaches for prenatal and postnatal application by our 
increased ability to interpret loss of function and hypomorphic variants alike. Furthermore, kinesins were extensively studied in cancer research and therapeutic strategies targeting their specific functions, such as the example of monastrol and other inhibitors of the mitotic kinesins may be adopted in the future. There are likely many more kinesinopathies to be unravelled in the field of birth defects because of their pivotal role in cellular logistics, but their recognition in clinics and research will depend on our ability to identify and characterise the common clinical, molecular and functional themes of these disorders and to use them to improve our understanding of their disease mechanisms.

Contributors SK and IF have both developed the concept and written the manuscript.

Funding The Swiss National Science Foundation (project grant number 320030_160200 awarded to IF) supported this work.

Competing interests None declared.

Patient consent for publication Not required.

Provenance and peer review Not commissioned; externally peer reviewed.

Open access This is an open access article distributed in accordance with the Creative Commons Attribution Non Commercial (CC BY-NC 4.0) license, which permits others to distribute, remix, adapt, build upon this work non-commercially, and license their derivative works on different terms, provided the original work is properly cited, appropriate credit is given, any changes made indicated, and the use is non-commercial. See: http://creativecommons.org/licenses/by-nc/4.0/.

ORCID iDs

Silvia Kalantari http://orcid.org/0000-0002-9459-9741

Isabel Filges http://orcid.org/0000-0002-2149-6354

\section{REFERENCES}

1 Vale RD, Reese TS, Sheetz MP. Identification of a novel force-generating protein, kinesin, involved in microtubule-based motility. Cell 1985;42:39-50.

2 Miki H, Setou M, Kaneshiro K, Hirokawa N. All kinesin superfamily protein, KIF, genes in mouse and human. Proc Natl Acad Sci U SA 2001;98:7004-11.

3 Hirokawa N, Noda Y, Tanaka Y, Niwa S. Kinesin superfamily motor proteins and intracellular transport. Nat Rev Mol Cell Biol 2009;10:682-96.

4 Zhao C, Takita J, Tanaka Y, Setou M, Nakagawa T, Takeda S, Yang HW, Terada S, Nakata T, Takei Y, Saito M, Tsuji S, Hayashi Y, Hirokawa N. Charcot-Marie-Tooth disease type 2A caused by mutation in a microtubule motor KIF1Bbeta. Cell 2001;105:587-97.

5 Hirokawa N, Tanaka Y. Kinesin superfamily proteins (KIFs): various functions and their relevance for important phenomena in life and diseases. Exp Cell Res 2015;334:16-25.

6 Zhong A, Tan F-Q, Yang W-X. Chromokinesin: kinesin superfamily regulating cell division through chromosome and spindle. Gene 2016;589:43-8.

7 Niwa S. Kinesin superfamily proteins and the regulation of microtubule dynamics in morphogenesis. Anat Sci Int 2015;90:1-6.

8 Osterman MJK, Kochanek KD, MacDorman MF, Strobino DM, Guyer B. Annual summary of vital statistics: 2012-2013. Pediatrics 2015;135:1115-25.

9 Wang D, Nitta R, Morikawa M, Yajima H, Inoue S, Shigematsu H, Kikkawa M, Hirokawa N. Motility and microtubule depolymerization mechanisms of the Kinesin-8 motor, KIF19A. Elife 2016;5:1-24.

10 Moawia A, Shaheen R, Rasool S, Waseem SS, Ewida N, Budde B, Kawalia A, Motameny S, Khan K, Fatima A, Jameel M, Ullah F, Akram T, Ali Z, Abdullah U, Irshad S, Höhne W, Noegel AA, Al-Owain M, Hörtnagel K, Stöbe P, Baig SM, Nürnberg P, Alkuraya FS, Hahn A, Hussain MS. Mutations of KIF14 cause primary microcephaly by impairing cytokinesis. Ann Neurol 2017;82:562-77.

11 Meier N, Bruder E, Lapaire O, Hoesli I, Kang A, Hench J, Hoeller S, De Geyter J, Miny $P$, Heinimann K, Chaoui R, Tercanli S, Filges I. Exome sequencing of fetal anomaly syndromes: novel phenotype-genotype discoveries. Eur J Hum Genet 2019;27:730-7.

12 Poirier K, Lebrun N, Broix L, Tian G, Saillour Y, Boscheron C, Parrini E, Valence S, Pierre BS, Oger M, Lacombe D, Geneviève D, Fontana E, Darra F, Cances C, Barth M, Bonneau D, Bernadina BD, N'guyen S, Gitiaux C, Parent P, des Portes V, Pedespan JM, Legrez V, Castelnau-Ptakine L, Nitschke P, Hieu T, Masson C, Zelenika D, Andrieux A, Francis F, Guerrini R, Cowan NJ, Bahi-Buisson N, Chelly J. Mutations in TUBG1, DYNC1H1, KIF5C and KIF2A cause malformations of cortical development and microcephaly. Nat Genet 2013;45:639-47.

13 Mohun T, Adams DJ, Baldock R, Bhattacharya S, Copp AJ, Hemberger M, Houart C, Hurles ME, Robertson E, Smith JC, Weaver T, Weninger W. Deciphering the mechanisms of developmental disorders (DMDD): a new programme for phenotyping embryonic lethal mice. Dis Model Mech 2013;6:562-6.
14 Chauvière M, Kress C, Kress M. Disruption of the mitotic kinesin Eg5 gene (Knsl1) results in early embryonic lethality. Biochem Biophys Res Commun 2008;372:513-9.

15 Lin F, Hiesberger T, Cordes K, Sinclair AM, Goldstein LSB, Somlo S, Igarashi P. Kidneyspecific inactivation of the KIF3A subunit of kinesin-II inhibits renal ciliogenesis and produces polycystic kidney disease. Proc Natl Acad Sci U SA 2003;100:5286-91.

16 Nonaka S, Tanaka Y, Okada Y, Takeda S, Harada A, Kanai Y, Kido M, Hirokawa N. Randomization of left-right asymmetry due to loss of nodal cilia generating leftward flow of extraembryonic fluid in mice lacking KIF3B motor protein. Cell 1998;95:829-37.

17 Tanaka Y, Kanai Y, Okada Y, Nonaka S, Takeda S, Harada A, Hirokawa N. Targeted disruption of mouse conventional kinesin heavy chain, kif5B, results in abnormal perinuclear clustering of mitochondria. Cell 1998;93:1147-58.

18 Ueno H, Huang X, Tanaka Y, Hirokawa N. KIF16B/Rab14 molecular motor complex is critical for early embryonic development by transporting FGF receptor. Dev Cell 2011;20:60-71.

19 Zhou R, Niwa S, Homma N, Takei Y, Hirokawa N. KIF26A is an unconventional kinesin and regulates GDNF-Ret signaling in enteric neuronal development. Cell 2009;139:802-13.

20 Wang L, Tanaka Y, Wang D, Morikawa M, Zhou R, Homma N, Miyamoto Y, Hirokawa N. The Atypical Kinesin KIF26A Facilitates Termination of Nociceptive Responses by Sequestering Focal Adhesion Kinase. Cell Rep 2018;24:2894-907.

21 Reilly ML, Benmerah A. Ciliary kinesins beyond IFT: cilium length, disassembly, cargo transport and signalling. Biol Cell 2019;111:79-94.

22 Putoux A, Thomas S, Coene KLM, Davis EE, Alanay Y, Ogur G, Uz E, Buzas D, Gomes C, Patrier S, Bennett CL, Elkhartoufi N, Frison M-HS, Rigonnot L, Joyé N, Pruvost $S$, Utine GE, Boduroglu K, Nitschke P, Fertitta L, Thauvin-Robinet C, Munnich A, Cormier-Daire V, Hennekam R, Colin E, Akarsu NA, Bole-Feysot C, Cagnard N, Schmitt A, Goudin N, Lyonnet S, Encha-Razavi F, Siffroi J-P, Winey M, Katsanis N, Gonzales M, Vekemans M, Beales PL, Attié-Bitach T. KIF7 mutations cause fetal hydrolethalus and acrocallosal syndromes. Nat Genet 2011;43:601-6.

23 Melo US, Macedo-Souza LI, Figueiredo T, Muotri AR, Gleeson JG, Coux G, Armas P, Calcaterra NB, Kitajima JP, Amorim S, Olávio TR, Griesi-Oliveira K, Coatti GC, Rocha CRR, Martins-Pinheiro M, Menck CFM, Zaki MS, Kok F, Zatz M, Santos S. Overexpression of KLC2 due to a homozygous deletion in the non-coding region causes SPOAN syndrome. Hum Mol Genet 2015;24:6877-85.

24 Yamada K, Andrews C, Chan W-M, McKeown CA, Magli A, de Berardinis T, Loewenstein A, Lazar M, O'Keefe M, Letson R, London A, Ruttum M, Matsumoto $N$, Saito N, Morris L, Del Monte M, Johnson RH, Uyama E, Houtman WA, de Vries B, Carlow TJ, Hart BL, Krawiecki N, Shoffner J, Vogel MC, Katowitz J, Goldstein SM, Levin AV, Sener EC, Ozturk BT, Akarsu AN, Brodsky MC, Hanisch F, Cruse RP, Zubcov AA, Robb RM, Roggenkäemper P, Gottlob I, Kowal L, Battu R, Traboulsi El, Franceschini P, Newlin A, Demer JL, Engle EC. Heterozygous mutations of the kinesin KIF21A in congenital fibrosis of the extraocular muscles type 1 (CFEOM1). Nat Genet 2003;35:318-21.

25 Duis J, Dean S, Applegate C, Harper A, Xiao R, He W, Dollar JD, Sun LR, Waberski MB, Crawford TO, Hamosh A, Stafstrom CE. KIF5A mutations cause an infantile onset phenotype including severe myoclonus with evidence of mitochondrial dysfunction. Ann Neurol 2016;80:633-7.

26 Ma D-D, Wang D-H, Yang W-X. Kinesins in spermatogenesis. Biol Reprod 2017;96:267-76

27 Camlin NJ, McLaughlin EA, Holt JE. Motoring through: the role of kinesin superfamily proteins in female meiosis. Hum Reprod Update 2017;23:409-20.

28 Rath 0, Kozielski F. Kinesins and cancer. Nat Rev Cancer 2012;12:527-39.

29 Mayer TU, Kapoor TM, Haggarty SJ, King RW, Schreiber SL, Mitchison TJ. Small molecule inhibitor of mitotic spindle bipolarity identified in a phenotype-based screen. Science 1999;286:971-4.

30 Myers SM, Collins I. Recent findings and future directions for interpolar mitotic kinesin inhibitors in cancer therapy. Future Med Chem 2016;8:463-89.

31 Aulchenko YS, Hoppenbrouwers IA, Ramagopalan SV, Broer L, Jafari N, Hillert J, Link J, Lundström W, Greiner E, Dessa Sadovnick A, Goossens D, Van Broeckhoven C, Del-Favero J, Ebers GC, Oostra BA, van Duijn CM, Hintzen RQ. Genetic variation in the KIF1B locus influences susceptibility to multiple sclerosis. Nat Genet 2008;40:1402-3.

32 Goris A, Boonen S, D'hooghe M-B, Dubois B. Replication of KIF21B as a susceptibility locus for multiple sclerosis. J Med Genet 2010;47:775-6.

33 Brenner D, Yilmaz R, Müller K, Grehl T, Petri S, Meyer T, Grosskreutz J, Weydt P, Ruf W, Neuwirth C, Weber M, Pinto S, Claeys KG, Schrank B, Jordan B, Knehr A, Günther K, Hübers A, Zeller D, Kubisch C, Jablonka S, Sendtner M, Klopstock T, de Carvalho M, Sperfeld A, Borck G, Volk AE, Dorst J, Weis J, Otto M, Schuster J, Del Tredici K, Braak H, Danzer KM, Freischmidt A, Meitinger T, Strom TM, Ludolph AC, Andersen PM, Weishaupt JH, Weyen U, Hermann A, Hagenacker T, Koch JC, Lingor P, Göricke B, Zierz S, Baum P, Wolf J, Winkler A, Young P, Bogdahn U, Prudlo J, Kassubek J, German ALS network MND-NET. Hot-Spot KIF5A mutations cause familial ALS. Brain 2018;141:688-97.

34 Alsabban AH, Morikawa M, Tanaka Y, Takei Y, Hirokawa N. Kinesin Kif3b mutation reduces NMDAR subunit NR 2A trafficking and causes schizophrenia-like phenotypes in mice. Embo J 2020;39:1-19.

35 Tarabeux J, Champagne N, Brustein E, Hamdan FF, Gauthier J, Lapointe M, Maios C, Piton A, Spiegelman D, Henrion E, Millet B, Rapoport JL, Delisi LE, Joober R, 
Fathalli F, Fombonne E, Mottron L, Forget-Dubois N, Boivin M, Michaud JL, Lafrenière RG, Drapeau P, Krebs M-O, Rouleau GA, Synapse to Disease Team. De novo truncating mutation in kinesin 17 associated with schizophrenia. Biol Psychiatry 2010;68:649-56.

36 Filges I, Friedman JM. Exome sequencing for gene discovery in lethal fetal disorders-harnessing the value of extreme phenotypes. Prenat Diagn 2015;35:1005-9.

37 Filges I, Nosova E, Bruder E, Tercanli S, Townsend K, Gibson WT, Röthlisberger B, Heinimann K, Hall JG, Gregory-Evans CY, Wasserman WW, Miny P, Friedman JM. Exome sequencing identifies mutations in KIF14 as a novel cause of an autosomal recessive lethal fetal ciliopathy phenotype. Clin Genet 2014:86:220-8.

38 Fujikura K, Setsu T, Tanigaki K, Abe T, Kiyonari H, Terashima T, Sakisaka T. Kif14 mutation causes severe brain malformation and hypomyelination. PLoS One 2013;8:e53490

39 Carleton M, Mao M, Biery M, Warrener P, Kim S, Buser C, Marshall CG, Fernandes C. Annis J, Linsley PS. RNA interference-mediated silencing of mitotic kinesin KIF14 disrupts cell cycle progression and induces cytokinesis failure. Mol Cell Biol 2006:26:3853-63.

40 Gruneberg U, Neef R, Li X, Chan EHY, Chalamalasetty RB, Nigg EA, Barr FA. KIF14 and citron kinase act together to promote efficient cytokinesis. J Cell Biol 2006;172:363-72.

41 Makrythanasis P, Maroofian R, Stray-Pedersen A, Musaev D, Zaki MS, Mahmoud IG, Selim L, Elbadawy A, Jhangiani SN, Coban Akdemir ZH, Gambin T, Sorte HS, Heiberg A, McEvoy-Venneri J, James KN, Stanley V, Belandres D, Guipponi M, Santoni FA, Ahangari N, Tara F, Doosti M, Iwaszkiewicz J, Zoete V, Backe PH, Hamamy H, Gleeson JG, Lupski JR, Karimiani EG, Antonarakis SE. Biallelic variants in KIF14 cause intellectual disability with microcephaly. Eur I Hum Genet 2018;26:330-9.

42 Reilly ML, Stokman MF, Magry V, Jeanpierre C, Alves M, Paydar M, Hellinga J, Delous M, Pouly D, Failler M, Martinovic J, Loeuillet L, Leroy B, Tantau J, Roume J, GregoryEvans CY, Shan X, Filges I, Allingham JS, Kwok BH, Saunier S, Giles RH, Benmerah A. Loss-Of-Function mutations in KIF14 cause severe microcephaly and kidney development defects in humans and zebrafish. Hum Mol Genet 2019;28:778-95.

43 Jayaraman D, Bae B-I, Walsh CA. The genetics of primary microcephaly. Annu Rev Genomics Hum Genet 2018;19:177-200.

44 Heidet L, Morinière V, Henry C, De Tomasi L, Reilly ML, Humbert C, Alibeu O, Fourrage C, Bole-Feysot C, Nitschké P, Tores F, Bras M, Jeanpierre M, Pietrement C, Gaillard D, Gonzales M, Novo R, Schaefer E, Roume J, Martinovic J, Malan V, Salomon R, Saunier S, Antignac C, Jeanpierre C. Targeted Exome Sequencing Identifies PBX1 as Involved in Monogenic Congenital Anomalies of the Kidney and Urinary Tract. J Am Soc Nephrol 2017;28:2901-14.

45 Dubreuil V, Marzesco A-M, Corbeil D, Huttner WB, Wilsch-Bräuninger M. Midbody and primary cilium of neural progenitors release extracellular membrane particles enriched in the stem cell marker prominin-1. J Cell Biol 2007;176:483-95.

46 Lang PY, Gershon TR. A new way to treat brain tumors: targeting proteins coded by microcephaly genes? Bioessays 2018;40.

47 Valence S, Poirier K, Lebrun N, Saillour Y, Sonigo P, Bessières B, Attié-Bitach T, Benachi A, Masson C, Encha-Razavi F, Chelly J, Bahi-Buisson N. Homozygous truncating mutation of the KBP gene, encoding a KIF1B-binding protein, in a familial case of fetal polymicrogyria. Neurogenetics 2013:14:215-24.

48 Ostergaard P, Simpson MA, Mendola A, Vasudevan P, Connell FC, van Impel A, Moore AT, Loeys BL, Ghalamkarpour A, Onoufriadis A, Martinez-Corral I, Devery S, Leroy JG, van Laer L, Singer A, Bialer MG, McEntagart M, Quarrell O, Brice G, Trembath RC,
Schulte-Merker S, Makinen T, Vikkula M, Mortimer PS, Mansour S, Jeffery S. Mutations in KIF11 cause autosomal-dominant microcephaly variably associated with congenital lymphedema and chorioretinopathy. Am J Hum Genet 2012;90:356-62.

49 Alsahli S, Arold ST, Alfares A, Alhaddad B, Al Balwi M, Kamsteeg E-J, Al-Twaijiri W, Alfadhel M. KIF16B is a candidate gene for a novel autosomal-recessive intellectual disability syndrome. Am J Med Genet A 2018;176:1602-9.

50 Wojcik MH, Okada K, Prabhu SP, Nowakowski DW, Ramsey K, Balak C, Rangasamy S, Brownstein CA, Schmitz-Abe K, Cohen IS, Fatemi A, Shi J, Grant EP, Narayanan V, Ho H-YH, Agrawal PB. De novo variant in KIF26B is associated with pontocerebellar hypoplasia with infantile spinal muscular atrophy. Am J Med Genet $A$ 2018;176:2623-9.

51 Lee J-R, Srour M, Kim D, Hamdan FF, Lim S-H, Brunel-Guitton C, Décarie J-C, Rossignol E, Mitchell GA, Schreiber A, Moran R, Van Haren K, Richardson R, Nicolai J, Oberndorf KMEJ, Wagner JD, Boycott KM, Rahikkala E, Junna N, Tyynismaa H, Cuppen I, Verbeek NE, Stumpel CTRM, Willemsen MA, de Munnik SA, Rouleau GA, Kim E, Kamsteeg E-J, Kleefstra T, Michaud JL. De novo mutations in the motor domain of KIF1A cause cognitive impairment, spastic paraparesis, axonal neuropathy, and cerebellar atrophy. Hum Mutat 2015;36:69-78.

52 Westland R, Verbitsky M, Vukojevic K, Perry BJ, Fasel DA, Zwijnenburg PJG, Bökenkamp A, Gille JJP, Saraga-Babic M, Ghiggeri GM, D'Agati VD, Schreuder MF, Gharavi AG, van Wijk JAE, Sanna-Cherchi S. Copy number variation analysis identifies novel CAKUT candidate genes in children with a solitary functioning kidney. Kidney Int 2015;88:1402-10.

53 Mirzaa GM, Vitre B, Carpenter G, Abramowicz I, Gleeson JG, Paciorkowski AR, Cleveland DW, Dobyns WB, O'Driscoll M. Mutations in CENPE define a novel kinetochore-centromeric mechanism for microcephalic primordial dwarfism. Hum Genet 2014;133:1023-39

54 Sleiman PMA, March M, Nguyen K, Tian L, Pellegrino R, Hou C, Dridi W, Sager M, Housawi YH, Hakonarson H. Loss-Of-Function mutations in KIF15 underlying a Braddock-Carey Genocopy. Hum Mutat 2017;38:507-10.

55 Bastian M, Heymann S, Jacomy M. Gephi: an open source software for exploring and manipulating networks 2009. Proceedings of the Third International Conference on Weblogs and Social Media, ICWSM; May 17-20, San Jose, California, USA, 2009:1-2.

56 Badano JL, Mitsuma N, Beales PL, Katsanis N. The ciliopathies: an emerging class of human genetic disorders. Annu Rev Genomics Hum Genet 2006;7:125-48.

57 Rauen KA. The RASopathies. Annu Rev Genomics Hum Genet 2013;14:355-69.

58 Dimassi S, Labalme A, Ville D, Calender A, Mignot C, Boutry-Kryza N, de Bellescize J, Rivier-Ringenbach C, Bourel-Ponchel E, Cheillan D, Simonet T, Maincent K, Rossi M, Till M, Mougou-Zerelli S, Edery P, Saad A, Heron D, des Portes V, Sanlaville D, Lesca G. Whole-exome sequencing improves the diagnosis yield in sporadic infantile spasm syndrome. Clin Genet 2016;89:198-204.

59 Nibbeling EAR, Duarri A, Verschuuren-Bemelmans CC, Fokkens MR, Karjalainen JM, Smeets CJLM, de Boer-Bergsma JJ, van der Vries G, Dooijes D, Bampi GB, van Diemen C, Brunt E, Ippel E, Kremer B, Vlak M, Adir N, Wijmenga C, van de Warrenburg BPC, Franke L, Sinke RJ, Verbeek DS. Exome sequencing and network analysis identifies shared mechanisms underlying spinocerebellar ataxia. Brain 2017:140:2860-78.

60 Ünlüsoy Aksu A, Das SK, Nelson-Williams C, Jain D, Özbay Hoşnut F, Evirgen Sahin G, Lifton RP, Vilarinho S. Recessive Mutations in KIF12 Cause High GammaGlutamyltransferase Cholestasis. Hepatol Commun 2019;3:471-7.

61 UniProt Consortium. UniProt: a worldwide hub of protein knowledge. Nucleic Acids Res 2019;47:D506-15. 